\title{
Expression of acidosis-dependent genes in human cancer nests
}

\author{
TOSHIHIKO FUKAMACHI ${ }^{1}$, SHUNSUKE IKEDA $^{1}$, HIROMI SAITO $^{1}$, \\ MASATOSHI TAGAWA ${ }^{2}$ and HIROSHI KOBAYASHI ${ }^{1}$ \\ ${ }^{1}$ Graduate School of Pharmaceutical Sciences, Chiba University, Chuo-ku, Chiba 260-8675; \\ ${ }^{2}$ Division of Pathology and Cell Therapy, Chiba Cancer Center Research Institute, Chuo-ku, Chiba 260-8717, Japan
}

Received January 24, 2014; Accepted June 30, 2014

DOI: $10.3892 / \mathrm{mco} .2014 .344$

\begin{abstract}
Previous studies investigating cancer cells cultured at acidic $\mathrm{pH}$ have shown that the expression level of $\sim 700$ genes were more than two-fold higher than those of the cells cultured in alkaline medium at $\mathrm{pH}$ 7.5. The aim of the present study was to confirm whether these acidosis-induced genes are expressed in human cancer tissues. Therefore, 7 genes were selected from our previous study, which encoded interleukin 32 (IL-32), lysosomal $\mathrm{H}^{+}$transporting ATPase, V0 subunit d2 (ATP6V0D2), tumor necrosis factor receptor superfamily, member 9 (TNFRSF9), amphiregulin, schwannoma-derived growth factor $(A R E G)$, v-erb-b2 erythroblastic leukemia viral oncogene homolog 3 (ErbB3), PRR5-ARHGAP8 (LOC553158) and dimethylglycine dehydrogenase $(D M G D H)$, and their expression was examined in human clinical specimens from patients with cancer. In addition, the expression of the gene encoding manganese superoxide dismutase $(M n S O D)$ was examined. The specimens from patients with colon, stomach and renal cancer showed increased MnSOD, IL-32, and TNFRSF9 transcripts compared to those from non-tumorous regions of the same patients. Notably, an elevated expression of ATP6VOD2 was found in the specimens from patients with stomach cancer, whereas the expression was decreased in those from patients with colon and renal cancer. The expression of LOC553158 was upregulated in colon and stomach cancer specimens. These results indicate that the investigation of gene expression under acidic conditions is useful for the development of novel cancer markers and/or chemotherapeutic targets.
\end{abstract}

\section{Introduction}

In the central regions of solid tumors, the extracellular $\mathrm{pH}$ falls below $\mathrm{pH} 6.5$ as a consequence of lactate accumulation, which is caused by hypoxic conditions produced by a lack of sufficient vascularization $(1,2)$ or an increase in tumor-specific

Correspondence to: Professor Hiroshi Kobayashi, Graduate School of Pharmaceutical Sciences, Chiba University, 1-8-1, Inohana, Chuo-ku, Chiba 260-8675, Japan

E-mail: hiroshi.k@mx6.ttcn.ne.jp

Key words: gene expression, human cancer, acidic environments glycolysis combined with impaired mitochondrial oxidative phosphorylation (3). Organ functions may be strongly affected by the disruption of the $\mathrm{pH}$ homeostasis as all the organs contain a large number of enzymes with $\mathrm{pH}$-sensitive catalytic activity. Therefore, it can be argued that alternative metabolic processes are activated under acidic conditions to compensate for the decline in processes functioning at alkaline $\mathrm{pH}$.

When various metabolic processes are working under different $\mathrm{pH}$ conditions, the efficacy of a number of inhibitors under acidic conditions may be different to those observed in conventional alkaline media. Impaired efficacy of paclitaxel, mitoxantrone and topotecan has been previously reported at $\mathrm{pH} 6.5$ as compared to their efficacy at $\mathrm{pH} 7.4$ in murine EMT6 and human MGH-U1 cells (4), and acidic conditions induced daunorubicin resistance by increasing the activity of p-glycoprotein via p38 activation in rat prostate cancer cells (5).

Malignant pleural mesothelioma is an aggressive tumor associated with asbestos exposure, and its prognosis is extremely poor (6). Mesothelioma shows resistance against numerous chemotherapeutic reagents (7). Our previous study found that statins inhibited the proliferation of mesothelioma cells strongly in an acidic medium with a $\mathrm{pH}$ that was close to the $\mathrm{pH}$ of an area of cancer in vivo (8). Statins, which are inhibitors of mevalonate synthesis, are prescribed for hyperlipidemia as the inhibition of mevalonate synthesis reduces blood cholesterol levels. However, the anti-cancer activity of statins has not been demonstrated in vitro. Recently, clinical studies have revealed that stains are effective at attenuating the growth of cancer cells in vivo $(9,10)$, in agreement with our previous in vitro observations at acidic $\mathrm{pH}(8)$. A previous study has shown that the anticancer activity is caused by the inhibition of geranylgeranyl diphosphate, derived from mevalonate, indicated that the function of certain geranylgeranylated proteins is essential for cell proliferation under acidic conditions $(8,11)$. In addition to the investigations with inhibitors, our previous studies found that different signal transduction pathways function under acidic environments $(12,13)$, and that $\mathrm{C}$-Terminus protein of $\mathrm{I} \chi \mathrm{B}-\beta$, which is an $\mathrm{I} \chi \mathrm{B}-\beta$ variant, acted as a critical transcriptional regulatory factor at $\mathrm{pH} 6.3$ only, and not at pH $7.4(14,15)$.

These previous findings indicate that numerous proteins are functioning preferentially under low $\mathrm{pH}$ conditions. DNA array analysis showed that the expression of $~ 700$ genes was elevated more than two-fold in mesothelioma cells under acidic conditions compared to in cells cultured in an 
alkaline medium (16). Numerous genes were also found to be strongly expressed in breast cancer cells cultured in an acidic medium (17). These gene products may be good candidate therapeutic targets and/or diagnostic markers of cancers. In the present study, the aim was to confirm whether or not the genes with an increased expression in cancer cells cultured in acidic medium are expressed in human cancer nests. A total of 8 genes with an increased expression in mesothelioma cells cultured under acidic conditions were selected and the expression was examined in human specimens from patients with cancer. The expression of the selected genes was demonstrated to be higher in numerous human cancer specimens compared to those in the specimens prepared from the surrounding normal areas.

\section{Materials and methods}

Human specimens from patients. Human tumor and the corresponding non-tumorous tissues were obtained from the Chiba Cancer Center Tissue Bank (Chiba, Japan) and used in the study with permission from the Institutional Ethical Committees of Chiba Cancer Center and Chiba University.

RNA extraction from human specimens. The human tissues that were stored at $-80^{\circ} \mathrm{C}$ were mixed with ice-cold TRI reagent (Sigma-Aldrich, St. Louis, MO, USA). After 1 min on ice, the human tissues were homogenized on ice with a homogenizer until the pellets were broken and cell lysis was completed. Total RNA was isolated from the lysate according to the manufacturer's instructions for the TRI reagent.

Quantitative polymerase chain reaction ( $q P C R$ ). Total RNA $(1 \mu \mathrm{g})$, prepared as described above, was reverse-transcribed using ReverTra Ace (Toyobo Co., Ltd., Osaka, Japan) in a total volume of $20 \mu \mathrm{l}$ containing the random primer for 18S rRNA or the polyT primer for the targeted genes. qPCR amplification was performed with an ABI Prism 7000 Sequence Detection System (Applied Biosystems, Foster City, CA, USA) using the FastStart Universal SYBR Green Master (Rox) (Roche Diagnostics, Basel, Switzerland) according to the manufacturer's instructions. The PCR reaction was carried out with a mixture containing 12.5 $\mu \mathrm{l}$ PCR Master, $7.5 \mu \mathrm{M}$ of each sense and antisense primer, $25 \mathrm{ng}$ cDNA, and nuclease-free water in a total volume of $25 \mu \mathrm{l}$. The standard thermal profile for PCR amplification was $50^{\circ} \mathrm{C}$ for $2 \mathrm{~min}, 95^{\circ} \mathrm{C}$ for $10 \mathrm{~min}$ and 40 cycles of $95^{\circ} \mathrm{C}$ for $15 \mathrm{sec}$ and $60^{\circ} \mathrm{C}$ for $60 \mathrm{sec}$. The primers used are shown in Table I.

A previous study has reported that the content of ribosomes per cell is $\sim 4 \times 10^{6}$ (18), and the amount of mRNA per cell can be estimated using $18 \mathrm{~S}$ rRNA as a control RNA with the following equation, in which $\mathrm{Ct}$ is the threshold cycle number: $4 \times 10^{6} \times 2^{\{(\mathrm{Ct} \text { of } 18 \mathrm{~S} \text { rRNA) - (Ct of sample RNA })\}}$.

\section{Results}

Quantification of $m R N A$ levels in human cancer specimens. Our previous study showed that the expression of 58 genes was elevated more than three-fold in mesothelioma cells cultured for $24 \mathrm{~h}$ in an acidic medium (16). The 58 genes are listed in Table II. Seven genes were selected of the 58 genes with various
Table I. Primers used in the present study.

\begin{tabular}{|c|c|}
\hline Gene name & Sequence \\
\hline 18S rRNA & $\begin{array}{l}\text { F: TAGAGTGTTCAAAGCAGGCCC } \\
\text { R: CCAACAAATAGAACCGCGGT }\end{array}$ \\
\hline$M n S O D$ & $\begin{array}{l}\text { F: TGAACG TCA CCG AGG AGA AG } \\
\text { R: CGT GCT CCC ACA CAT CAA TC }\end{array}$ \\
\hline$I L-32$ & $\begin{array}{l}\text { F: TCAAAGAGGGCTACCTGGAG } \\
\text { R: TTTCAAGTAGAGGAGTGAGCTCTC }\end{array}$ \\
\hline ATP6VOD2 & $\begin{array}{l}\text { F: GACCCAGCAAGACTATATCAACC } \\
\text { R: TGGAGATGAATTTTCAGGTCTTC }\end{array}$ \\
\hline TNFRSF9 & $\begin{array}{l}\text { F: AAACGGGGCAGAAAGAAACT } \\
\text { R: CTTCTGGAAATCGGCAGCTA }\end{array}$ \\
\hline$A R E G$ & $\begin{array}{l}\text { F: GGGAGTGAGATTTCCCCTGT } \\
\text { R: AGCCAGGTATTTGTGGTTCG }\end{array}$ \\
\hline ErbB3 & $\begin{array}{l}\text { F: TGCAGTGGATTCGAGAAGTG } \\
\text { R: GGCAAACTTCCCATCGTAGA }\end{array}$ \\
\hline LOC 553158 & $\begin{array}{l}\text { F: AGCCTCCCAGAGCACAACTA } \\
\text { R: ATGGCCAGATCAAATTCAGC }\end{array}$ \\
\hline$D M G D H$ & $\begin{array}{l}\text { F: GAGCTCACGGCTGGATCTAC } \\
\text { R: CCACCACCTGACCAGTTTCT }\end{array}$ \\
\hline
\end{tabular}

$M n S O D$, manganese superoxide dismutase; IL-32, interleukin 32; ATP6VOD2, lysosomal $\mathrm{H}^{+}$transporting ATPase, V0 subunit d2; TNFRSF9, tumor necrosis factor receptor superfamily, member 9; $A R E G$, amphiregulin, schwannoma-derived growth factor; ErbB3,v-erb-b2 erythroblastic leukemia viral oncogene homolog 3; LOC553158, PRR5-ARHGAP8; DMGDH, dimethylglycine dehydrogenase.

functions, which were interleukin 32 (IL-32), lysosomal $\mathrm{H}^{+}$ transporting ATPase, V0 subunit d2 (ATP6VOD2), tumor necrosis factor receptor superfamily, member 9 (TNFRSF9), amphiregulin, schwannoma-derived growth factor $(A R E G)$, v-erb-b2 erythroblastic leukemia viral oncogene homolog 3 (ErbB3), PRR5-ARHGAP8 (LOC553158) and dimethylglycine dehydrogenase $(D M G D H)$, and the expression of these genes was examined in human cancer specimens. In addition, the expression of the gene encoding manganese superoxide dismutase $(M n S O D)$ was examined as MnSOD has been reported to participate in gastric and colorectal tumor metastasis $(19,20)$, although the expression of MnSOD at acidic $\mathrm{pH}$ was 1.6-fold in mesothelioma cells. The selected genes are shown in Table II.

One problem in the measurement of mRNA using qPCR was determining which was useful as a control RNA. Thus far, a reference gene, such as $G A P D H$, has generally been used in studies. There are no previous data to show that the expression of such reference genes is stable at acidic $\mathrm{pH}$, particularly in human cancer nests. The amount of 18S rRNA was constant in mesothelioma cells at acidic and alkaline $\mathrm{pH}$ (data not shown). The amount of 18S rRNA in total RNA isolated from human cancer specimens was measured, with the results demonstrating that the content of 18S rRNA was constant in all the cancer specimens (Table III). The amount of $18 \mathrm{~S}$ rRNA was slightly higher in normal areas, but the difference was $<2$-fold. These data indicated that 18S rRNA was suitable for use as 
Table II. Genes with an elevated expression of $>3$-fold at acidic $\mathrm{pH}$.

\begin{tabular}{|c|c|c|c|}
\hline Gene & $\begin{array}{l}\text { Expression at } \\
\text { pH } 6.7 \text { (fold) }^{\mathrm{a}}\end{array}$ & $\begin{array}{l}\text { Relative } \\
\text { amount }^{\mathrm{b}}\end{array}$ & Description \\
\hline RHCE & 7.816 & 0.58 & Rh blood group, CcEe antigens \\
\hline RSPO3 & 7.346 & 0.70 & R-spondin 3 homolog (Xenopus laevis) \\
\hline ZSCAN4 & 6.346 & 1.06 & zinc finger and SCAN domain containing 4 \\
\hline $\operatorname{ErbB3}^{\mathrm{c}}$ & 5.997 & 0.69 & v-erb-b2 erythroblastic leukemia viral oncogene homolog 3 (avian) \\
\hline$A R E G^{\mathrm{c}}$ & 5.650 & 0.92 & amphiregulin (schwannoma-derived growth factor) \\
\hline FLJ33706 & 5.579 & 1.75 & hypothetical protein FLJ33706 \\
\hline TNFRSF9' & 5.464 & 2.58 & tumor necrosis factor receptor superfamily, member 9 \\
\hline$B M P 1$ & 5.186 & 0.40 & bone morphogenetic protein 1 \\
\hline PIPOX & 5.069 & 0.66 & pipecolic acid oxidase \\
\hline LOC653193 & 4.485 & 0.43 & $\begin{array}{l}\text { similar to Amphiregulin precursor (AR) (Colorectum cell-derived growth } \\
\text { factor) (CRDGF) }\end{array}$ \\
\hline$D M G D H^{\mathrm{c}}$ & 4.310 & 0.39 & dimethylglycine dehydrogenase \\
\hline $\operatorname{LOC} 553158^{\mathrm{c}}$ & 4.306 & 0.44 & PRR5-ARHGAP8 fusion \\
\hline KCTD19 & 4.231 & 0.33 & potassium channel tetramerisation domain containing 19 \\
\hline ZC 3 H6 & 4.220 & 0.15 & zinc finger $\mathrm{CCCH}$-type containing 6 \\
\hline SIGLEC1 & 4.184 & 0.29 & sialic acid binding Ig-like lectin 1 , sialoadhesin \\
\hline GRHL3 & 4.142 & 0.54 & grainyhead-like 3 (Drosophila) \\
\hline FBXO32 & 4.117 & 1.49 & F-box protein 32 \\
\hline$B M P 2$ & 4.014 & 0.48 & bone morphogenetic protein 2 \\
\hline$L X N$ & 3.987 & 9.88 & latexin \\
\hline INPP5D & 3.967 & 0.49 & inositol polyphosphate-5-phosphatase, $145 \mathrm{kDa}$ \\
\hline RARRES1 & 3.882 & 0.49 & retinoic acid receptor responder (tazarotene induced) 1 \\
\hline NYD-SP14 & 3.847 & 0.48 & NYD-SP14 protein \\
\hline$R R A D$ & 3.827 & 4.50 & Ras-related associated with diabetes \\
\hline$V W C E$ & 3.790 & 2.35 & von Willebrand factor $\mathrm{C}$ and EGF domains \\
\hline$A T P 6 V 0 D 2^{\mathrm{c}}$ & 3.778 & 0.69 & ATPase, $\mathrm{H}^{+}$transporting, lysosomal $38 \mathrm{kDa}, \mathrm{V} 0$ subunit d2 \\
\hline $\mathrm{CDH} 15$ & 3.750 & 0.64 & cadherin 15, M-cadherin (myotubule) \\
\hline HES 2 & 3.723 & 0.54 & hairy and enhancer of split 2 (Drosophila) \\
\hline$I L-32^{\mathrm{c}}$ & 3.711 & 8.91 & interleukin 32 \\
\hline CRELDI & 3.707 & 2.92 & cysteine-rich with EGF-like domains 1 \\
\hline$P P P 1 R 3 E$ & 3.702 & 0.39 & protein phosphatase 1 , regulatory (inhibitor) subunit $3 \mathrm{E}$ \\
\hline CLDN14 & 3.560 & 0.20 & claudin 14 \\
\hline ARHGAP8 & 3.547 & 0.23 & Rho GTPase activating protein 8 \\
\hline MGC33926 & 3.508 & 5.58 & hypothetical protein MGC33926 \\
\hline LOC390937 & 3.497 & 0.34 & similar to ETS domain transcription factor ERF \\
\hline FUT5 & 3.486 & 0.41 & fucosyltransferase $5(\alpha(1,3)$ fucosyltransferase $)$ \\
\hline$C L E C 4 F$ & 3.459 & 0.47 & C-type lectin domain family 4 , member $\mathrm{F}$ \\
\hline LOC644893 & 3.363 & 0.21 & hypothetical protein LOC644893 \\
\hline C11orf34 & 3.359 & 0.83 & chromosome 11 open reading frame 34 \\
\hline EGR4 & 3.353 & 0.13 & early growth response 4 \\
\hline FLJ42258 & 3.324 & 0.56 & FLJ42258 protein \\
\hline$C F B$ & 3.320 & 5.25 & complement factor B \\
\hline GPR78 & 3.302 & 0.92 & G protein-coupled receptor 78 \\
\hline$M U C 3 B$ & 3.300 & 0.49 & mucin 3B, cell surface associated \\
\hline$C R Y M$ & 3.298 & 1.48 & crystallin, $\mu$ \\
\hline CYYRl & 3.294 & 0.14 & cysteine/tyrosine-rich 1 \\
\hline LOC 196394 & 3.286 & 7.17 & hypothetical protein LOC196394 \\
\hline LOC644725 & 3.262 & 0.30 & $\begin{array}{l}\text { similar to } \gamma \text {-tubulin complex component } 3 \text { (GCP-3) (Spindle pole body } \\
\text { protein Spc98 homolog) (hSpc98) (hGCP3) (h104p) }\end{array}$ \\
\hline
\end{tabular}


Table II. Continued.

\begin{tabular}{lcrl}
\hline Gene & $\begin{array}{c}\text { Expression at } \\
\text { pH } 6.7(\text { fold })^{\mathrm{a}}\end{array}$ & $\begin{array}{c}\text { Relative } \\
\text { amount }^{\mathrm{b}}\end{array}$ & \\
\hline FGF7 & 3.219 & 0.17 & Description \\
PNLIPRP3 & 3.178 & 1.21 & $\begin{array}{l}\text { fibroblast growth factor 7 (keratinocyte growth factor) } \\
\text { pancreatic lipase-related protein 3 }\end{array}$ \\
clorf101 & 3.170 & 0.13 & chromosome 1 open reading frame 101 \\
ALS2CR7 & 3.164 & 0.49 & amyotrophic lateral sclerosis 2 (juvenile) chromosome region, candidate 7 \\
IGLL1 & 3.130 & 1.12 & immunoglobulin $\lambda$-like polypeptide 1 \\
GDF15 & 3.112 & 22.10 & growth differentiation factor 15 \\
FLJ26850 & 3.082 & 0.23 & FLJ26850 protein \\
PTP4A3 & 3.037 & 9.05 & protein tyrosine phosphatase type IVA, member 3 \\
TAS2R39 & 3.035 & 0.34 & taste receptor, type 2, member 39 \\
SGK2 & 3.015 & 0.28 & serum/glucocorticoid regulated kinase 2 \\
CRNN & 3.005 & 0.20 & cornulin \\
MnSOD & 1.599 & 13.77 & manganese superoxide dismutase \\
GAPDH & 0.962 & 100.00 & glyceraldehyde-3-phosphate dehydrogenase \\
\hline
\end{tabular}

${ }^{a}$ Expression ratio in cells cultured at $\mathrm{pH} 6.7$ for $24 \mathrm{~h}$ compared to $\mathrm{pH} 7.5$; ${ }^{\mathrm{b}}$ percent ratio of the mRNA level to the level of $18 \mathrm{~S}$ rRNA at $\mathrm{pH} 6.7$, ${ }^{\mathrm{c}}$ selected genes. For original DNA array data, see reference 16.

Table III. Amount of 18S rRNA in the human specimens from patients with colon, stomach, liver and renal cancer.

\begin{tabular}{lccc}
\hline & & \multicolumn{2}{c}{ Ct of $18 \mathrm{~S}$ rRNA $($ mean \pm SD) } \\
\cline { 3 - 4 } Tissues & Samples, $\mathrm{n}$ & Normal area & Cancer area \\
\hline Colon & 11 & $11.07 \pm 0.64$ & $11.71 \pm 0.58$ \\
Stomach & 10 & $11.03 \pm 0.55$ & $11.49 \pm 1.01$ \\
Renal & 10 & $10.97 \pm 0.69$ & $11.60 \pm 0.40$ \\
Liver & 10 & $10.63 \pm 0.54$ & $11.63 \pm 0.66$ \\
Total & 41 & $10.93 \pm 0.61$ & $11.61 \pm 0.67$ \\
\hline
\end{tabular}

$\mathrm{SD}$, standard deviation.

control RNA. The $\mathrm{Ct}$ value shown in Table III was similar to that observed in cells cultured in vitro (data not shown), suggesting that the ribosome content per cell is constant even when the activity of protein synthesis varies. As one cell was reported to have $\sim 4 \times 10^{6}$ ribosomes (18), the approximate copy number of mRNA can be calculated using this number. The mRNA level of GAPDH estimated using 18S rRNA as a control RNA decreased slightly at acidic $\mathrm{pH}$ in mesothelioma cells (Table II).

Expression levels of selected genes in human cancers. Specimens from patients with lung, colon, stomach, liver and renal cancer in the Chiba Cancer Center Tissue Bank were available for the study. The homogenates of specimens from patients with lung cancer were not used due to a huge amount of skeletal material, so the measurement of gene expression was not assessed. Therefore, the expression of 8 selected genes was examined in the specimens from patients with colon, stomach, liver and renal cancer.
The specimens from the colon, stomach and renal cancer tissues showed increased MnSOD, IL-32 and TNFRSF9 transcripts compared to those from the non-tumorous regions of the same patients (Fig. 1). Increased expression of AREG was found in colon and renal cancer specimens (Fig. 1). Notably, an elevated expression of ATP6VOD2 was found in stomach cancer specimens, whereas the expression was reduced in the specimens from patients with colon and renal cancer (Fig. 1). The expression of ErbB3 was shown to be higher in colon, stomach and liver cancer specimens compared to the normal tissues, but a higher expression was observed in less than half of the renal cancer samples (Fig. 1). An increased expression of LOC553158 was found in the specimens from the colon and stomach cancer nests, but the expression decreased in the liver and renal cancer specimens (Fig. 1). The expression of $D M G D H$ was upregulated in the specimens from the colon cancer tissues, and the upregulated expression was observed in about half of the samples from the patients with stomach, liver and renal cancer (Fig. 1).

\section{Discussion}

For $>30$ years, it has been well known that cancer nests are acidified. However, thus far, few in vitro studies using acidic medium to develop cancer markers and medicines for cancer therapies have been performed. Our previous studies suggested that in vitro screening of compounds with anti-proliferation activity in an acidic medium was useful for developing anti-cancer drugs (11). A >2-fold increase in expression was found in 700 genes in mesothelioma cells as the medium was acidified (16). Mesothelioma is one cancer that is hard to treat and remains asymptomatic even at a late stage.

In the present study, the expression of 8 genes with acidosis-induced expression in mesothelioma cells were examined in human specimens from various cancers and 

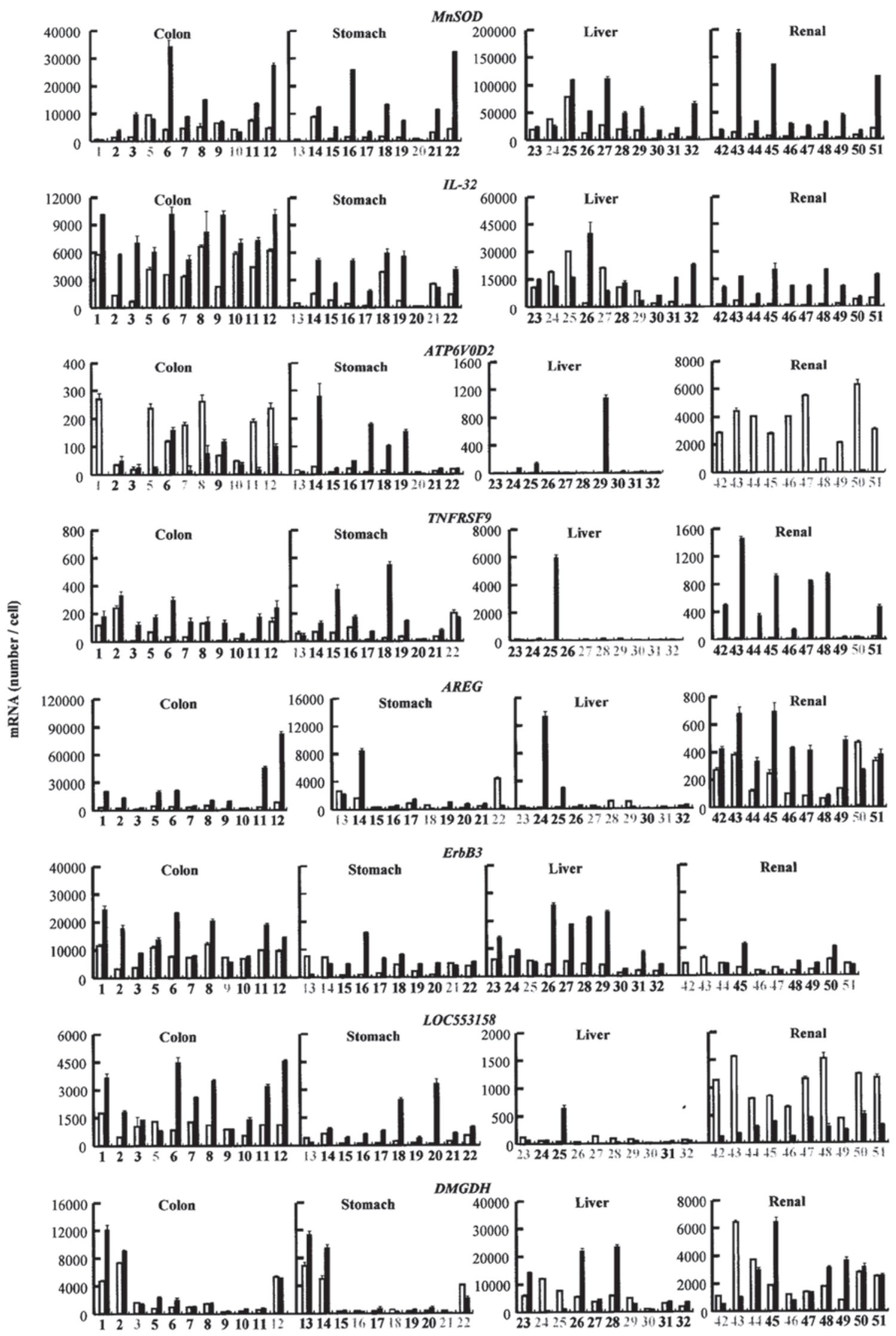

Figure 1. Gene expression in cancer tissues. RNA was extracted from human tumor (closed bars) and the corresponding non-tumorous tissues (open bars). The mRNA levels (MnSOD, IL-32, ATP6VOD2 and TNFRSF9; AREG, ErbB3, LOC553158 and DMGDH) were measured as described in the Materials and methods. The averages and standard deviation values were obtained from three experiments. The numbers in the horizontal axes correlate to the patient numbers. Grey numbers are the patients in which the gene expression decreased in the cancer tissues. $M n S O D$, manganese superoxide dismutase; $I L-32$, interleukin 32; ATP6VOD2, lysosomal $\mathrm{H}^{+}$transporting ATPase, V0 subunit d2; TNFRSF9, tumor necrosis factor receptor superfamily, member 9; AREG, amphiregulin, schwannoma-derived growth factor; ErbB3,v-erb-b2 erythroblastic leukemia viral oncogene homolog 3; LOC553158, PRR5-ARHGAP8; $D M G D H$, dimethylglycine dehydrogenase. 
corresponding normal tissues. The expression varied in different tissues and showed a large variation among patients (Fig. 1). There may be a possibility that the genes that are specific to acidosis are expressed in a normal tissue area close to cancer nests as such an area may be acidified even if it contains no cancer cells. However, it is difficult to measure the $\mathrm{pH}$ of normal tissues prior to surgery as it can change during surgery due to the limited supply of blood. Furthermore, the $\mathrm{pH}$ may vary in different areas of cancer nests. In particular, the areas far from blood vessels are strongly acidified as suggested previously (2). Even though the data showed a wide variation, the present study produced several noteworthy results.

IL-32, TNFRSF9, AREG, ErbB3, LOC553158 and $D M G D H$ were expressed at a higher level than that of the normal areas in almost all the colon cancer patients. $M n S O D$, IL-32, ATP6VOD2, TNFRSF9 and LOC553158 were expressed at a higher level compared to the normal areas in almost all the patients with stomach cancer. Therefore, these genes may be candidate therapeutic or diagnostic marker targets for these cancers, and a combination use of these genes may be particularly useful for future treatment. In the liver cancer area, $M n S O D$ and $E r b B 3$ were expressed at a higher level, but the expression of other genes was different in various patients. The reason for these differences in expression change remains unclear. Liver cancer nests may only be slightly acidified due to the highly organized blood vessel network in the liver.

IL-32 is a notable cytokine. This cytokine has been indicated to have a role in immune responses (21). The present data indicates that IL-32 is an interleukin that is specific to acidic conditions. As the mRNA level of $I L-32$ was high in mesothelioma cells cultured at acidic $\mathrm{pH}\left(2.6 \times 10^{5}\right.$ copies/cell, calculated from the data shown in Table II) and the numerous cancer nests measured in the present study (Fig. 1), this interleukin may be a predominant candidate for cancer diagnosis as indicated recently (22). TNFRSF9 has been suggested to play significant roles in immune responses (23). Our previous study demonstrated that the expression of TNFRSF9 is induced in mesothelioma cells cultured in acidic media (16) and numerous cancer specimens (Fig. 1). Immune cells have to infiltrate into cancer nests or inflammatory loci to rehabilitate damaged tissues. Since cancer and inflammatory areas are often acidified, IL-32 and TNFRSF9 may function under acidic conditions in various cells besides the immune cells.

The ErbB/HER family, HER1 (epidermal growth factor receptor), HER2 (ErbB2), HER3 (ErbB3), and HER4 (ErbB4), has been indicated to have a central role in a wide variety of growth factor-dependent cell responses (24). This family has been shown to mediate differentiation in neuroblastoma (25), and a high expression of $E r b B 3$ was found in neuroblastic tumors (26). High expression of $E r b B 3$ was also found in various cancers, and $E r b B 3$ has been identified as an attractive therapeutic target (27). Taken together with the present data, it can be argued that the gene product of $E r b B 3$ protects against cell death under acidic conditions. AREG was found to be expressed at high levels in colon and renal cancers, suggesting a role in carcinogenesis $(28,29)$. To the best of our knowledge, this is the first study to report the expression of LOC553158 itself in cancer cells, but the upregulation of $A R H G A P 8$ has been reported in cervical cancer (30).
DMGDH is a mitochondrial enzyme that has a role in choline catabolism [NCBI data base (31)]. No data concerning the role of DMGDH in carcinogenesis has been reported until the present study, and furthermore, no data to show the activation of the mitochondrial function in cancer cells has been reported. The present data indicate that choline catabolism may be activated in cancer areas or that DMGDH may mediate an unidentified metabolic process under acidic conditions besides choline catabolism.

The expression pattern of ATP6VOD2 in renal tissues was unique. High expression of this gene was detected in normal areas, whereas almost no expression was observed in the cancer areas of all the patients. Protons are extruded to urine (32), and therefore, urine is often acidified. A high expression of ATP6VOD2 has been previously reported in normal renal tissues (33). Therefore, it is quite possible that this gene is expressed in normal renal tissues to protect cells against external acidosis. The function to extrude protons may be diminished during carcinogenesis, resulting in the attenuation of this gene expression.

The genes with elevated expression levels in cancer specimens as compared to the surrounding normal tissues may be good candidates as novel targets and markers for cancer therapy. Particularly, a combination therapy may be more useful for the diagnosis of carcinogenesis and chemotherapeutics against cancer. The expression of 8 genes with high expression in cells cultured at an acidic $\mathrm{pH}$ were examined and it was found that the gene expression was elevated in human cancer tissues in the present study. Further studies of other acidosis-dependent gene expressions to promote the development of novel cancer markers and/or chemotherapeutic targets are warranted in future studies.

\section{Acknowledgements}

The authors would like to express their appreciation to Chiba Cancer Center Tissue Bank (Japan) for providing the human specimens. We thank Dr Xin Wang for her contribution to this section of the study.

\section{References}

1. Vaupel P, Kallinowski F and Okunieff P: Blood flow, oxygen and nutrient supply, and metabolic microenvironment of human tumors. Cancer Res 49: 6449-6465, 1989.

2. Dellian M, Helmlinger G, Yuan F and Jain RK: Fluorescence ratio imaging of interstitial $\mathrm{pH}$ in solid tumours: effect of glucose on spatial and temporal gradients. Br J Cancer 74: 1206-1215, 1996.

3. Warburg O: On the origin of cancer cells. Science 123: 309-314, 1956.

4. Vukovic V and Tannock IF: Influence of low $\mathrm{pH}$ on cytotoxicity of paclitaxel, mitoxantrone and topotecan. Br J Cancer 75: 1167-1172, 1997.

5. Sauvant C, Nowak M, Wirth C, et al: Acidosis induces multi-drug resistance in rat prostate cancer cells (AT1) in vitro and in vivo by increasing the activity of the p-glycoprotein via activation of p38. Int J Cancer 123: 2532-2542, 2008.

6. Zucali PA and Giaccone G: Biology and management of malignant pleural mesothelioma. Eur J Cancer 42: 2706-2714, 2006.

7. Catalano A, Rodilossi S, Rippo MR, Caprari P and Procopio A: Induction of stem cell factor/c-Kit/Slug signal transduction in multidrug-resistant malignant mesothelioma cells. J Biol Chem 279: 46706-46714, 2004.

8. Fukamachi T, Chiba Y, Wang X, et al: Tumor specific low $\mathrm{pH}$ environments enhance the cytotoxicity of lovastatin and cantharidin. Cancer Lett 297: 182-189, 2010. 
9. Nielsen SF, Nordestgaard BG and Bojesen SE: Statin use and reduced cancer-related mortality. N Engl J Med 367: 1792-1802, 2012.

10. Brewer TM, Masuda H and Liu DD: Statin use in primary inflammatory breast cancer: a cohort study. Br J Cancer 109: 318-324, 2013.

11. Fukamachi T, Wang X, Mochizuki Y, et al: Acidic environments enhance the inhibitory effect of statins on proliferation of synovial cells. Int Immunopharmacol 17: 148-153, 2013.

12. Fukamachi T, Saito H, Kakegawa T and Kobayashi H: Different proteins are phosphorylated under acidic environments in Jurkat cells. Immunol Lett 82: 155-158, 2002.

13. Hirata S, Fukamachi T, Sakano H, et al: Extracellular acidic environments induce phosphorylation of ZAP-70 in Jurkat T cells. Immunol Lett 115: 105-109, 2008.

14. Lao Q, Fukamachi T, Saito H, Kuge O, Nishijima M and Kobayashi H: Requirement of an IkappaB-beta $\mathrm{COOH}$ terminal region protein for acidic-adaptation in $\mathrm{CHO}$ cells. J Cell Physiol 207: 238-243, 2006.

15. Fukamachi T, Lao Q, Okamura S, Saito H and Kobayashi H: CTIB (C-Terminus protein of IkappaB-beta): a novel factor required for acidic adaptation. Adv Exp Med Biol 584: 219-228, 2006.

16. Fukamachi T, Ikeda S, Wang X, et al: Gene expressions for signal transduction under acidic conditions. Genes (Basel) 4: 65-85, 2013.

17. Tang X, Lucas JE, Chen JL, et al: Functional interaction between responses to lactic acidosis and hypoxia regulates genomic transcriptional outputs. Cancer Res 72: 491-502, 2012.

18. Darnel J, Lodish H and Baltimore D: Molecular Cell Biology. Scientific American Books, Inc., New York, NY, USA, 1986.

19. Malafa M, Margenthaler J, Webb B, Neitzel L and Christophersen M: MnSOD expression is increased in metastatic gastric cancer. J Surg Res 88: 130-134, 2000.

20. Meng X, Wu J, Pan C, et al: Genetic and epigenetic down-regulation of microRNA-212 promotes colorectal tumor metastasis via dysregulation of MnSOD. Gastroenterology 145: 426-436, 2013.

21. Joosten LA, Heinhuis B, Netea MG and Dinarello CA: Novel insights into the biology of interleukin-32. Cell Mol Life Sci 70: 3883-3892, 2013.

22. Ishigami S, Arigami T, Uchikado Y, et al: IL-32 expression is an independent prognostic marker for gastric cancer. Med Oncol 30: $472,2013$.
23. Zhao S, Zhang H, Xing Y and Natkunam Y: CD137 ligand is expressed in primary and secondary lymphoid follicles and in B-cell lymphomas: diagnostic and therapeutic implications. Am J Surg Pathol 37: 250-258, 2013.

24. Linggi B and Carpenter G: ErbB receptors: new insights on mechanisms and biology. Trends Cell Biol 16: 649-656, 2006.

25. Izycka-Swieszewska E, Wozniak A, Drozynska E, et al: Expression and significance of HER family receptors in neuroblastic tumors. Clin Exp Metastasis 28: 271-282, 2011.

26. Wilzén A, Krona C, Sveinbjörnsson B, et al: ERBB3 is a marker of a ganglioneuroblastoma/ganglioneuroma-like expression profile in neuroblastic tumours. Mol Cancer 12: 70, 2013.

27. Sithanandam G and Anderson LM: The ERBB3 receptor in cancer and cancer gene therapy. Cancer Gene Ther 15: 413-448, 2008.

28. Guzman MJ, Shao J and Sheng H: Pro-neoplastic effects of amphiregulin in colorectal carcinogenesis. J Gastrointest Cancer 44: 211-221, 2013.

29. Yotsumoto F, Yagi H, Suzuki SO, et al: Validation of HB-EGF and amphiregulin as targets for human cancer therapy. Biochem Biophys Res Commun 365: 555-561, 2008.

30. Song JY, Lee JK, Lee NW, et al: Microarray analysis of normal cervix, carcinoma in situ, and invasive cervical cancer: identification of candidate genes in pathogenesis of invasion in cervical cancer. Int J Gynecol Cancer 18: 1051-1059, 2008.

31. Binzak BA, Wevers RA, Moolenaar SH, et al: Cloning of dimethylglycine dehydrogenase and a new human inborn error of metabolism, dimethylglycine dehydrogenase deficiency. Am J Hum Genet 68: 839-847, 2001.

32. Zeidel ML, Silva P and Seifter JL: Intracellular $\mathrm{pH}$ regulation and proton transport by rabbit renal medullary collecting duct cells. Role of plasma membrane proton adenosine triphosphatase. J Clin Invest 77: 113-120, 1986.

33. Smith AN, Borthwick KJ and Karet FE: Molecular cloning and characterization of novel tissue-specific isoforms of the human vacuolar $\mathrm{H}^{+}$-ATPase $\mathrm{C}, \mathrm{G}$ and d subunits, and their evaluation in autosomal recessive distal renal tubular acidosis. Gene 297: 169-177, 2002. 